2020, Volume 10, International Conference Globalization, Innovation and Development. Trends and Prospects (G.I.D.T.P.), pages: 276-281 | https://doi.org/10.18662/lumproc/gidtp2018/31

\section{The Review - a Legal Remedy against International Law Opposability}

\section{Florin Octavian BARBU* ${ }^{1}$, Cristian MITROI ${ }^{2}$}

${ }^{1}$ Romanian Academy, The Institute of Juridical Research "Andrei Radulescu" Bucharest, Targoviste, Dambovita, email address:

florin_octavian2000@yahoo.com

Corresponding author

${ }^{2}$ Valahia University of Targoviste, Romania

\begin{abstract}
Legal remedies against opposability are mechanisms that aim at obtaining a court's withdrawal of its previous decision or the annulment or reformulation of the previously adopted decision. The system of the respective legal means, which, in fact represents different ways of appeal, is incomplete and differs from that provided by the national law. The review is a remedy reserved to sustainable courts, which consists in the possibility for the parties to draw a decision that was previously wrongly pronounced. It is a review of judgments that have been formulated on the basis of erroneous data (facts which at the time of the examination of the case were ignored and subsequently discovered) that played a decisive role in making a decision from an arbitrator or a judge. Art. 61 of the IJC Statute provides that the trial may be started without the consent of the other party and, implicitly, may be opened upon the submission of a unilateral request. As a rule, a review request is examined by the contentious party that issued the decision under review. The review request is solved in two stages. In the first stage, the Chamber or the Grand Chamber can declare of its own motion to reject the application on the ground that nothing justifies its examination. In the second stage, if the application was not rejected, the Registrar shall communicate it to all other interested parties, to submit any written observations within the time limit set by the Judge. The arbitration panels may also be subject to the review procedure in accordance with the conditions laid down in the 1907. Thus, according to Art. 83 of the Convention, in order to be able to use the review of the arbitral award, the parties are obliged to reserve this right in the arbitration agreement, which also stipulates the term in which a request for revision of the sentence may be filed.
\end{abstract}

Keywords: the remedies; sentence; the examination; arbitration agreement; Convention.

How to cite: Barbu, F.C., \& Mitroi, C. (2020). The Review a Legal Remedy against International Law Opposability. In I. Panagoreț \& G. Gorghiu (vol. ed.), Lumen Proceedings: Vol. 10. International Conference Globalization, Innovation and Development. Trends and Prospects (G.I.D.T.P.) (pp. 276-281). Iasi, Romania: LUMEN Publishing House. https://doi.org/10.18662/lumproc/gidtp2018/31 



\section{Introduction}

There is a remedy reserved to sustainable courts, which is the possibility for the parties to withdraw a decision that was previously wrongly pronounced. It is a review of judgments that have been formulated on the basis of erroneous data (facts which at the time of the examination of the case have been ignored and subsequently discovered) which have played a decisive role in making a decision on the part of an arbitrator or a judge. For example, provided in the Statute of the ICJ (Article 61), the trial may be started even if the other party's consent is obtained and implicitly opens upon the submission of a unilateral request.

\section{Terms for review}

A request for review may be submitted to the IJC only if the following conditions are met cumulatively:

1 - the application is based on the discovery of a „,new fact";

2 - the newly discovered fact must be capable of exerting a decisive influence on the judgment;

3 - the fact found must not have been known to the Court or to the party requesting the review until judgment has been given;

4 - ignorance of the fact must not result from the negligence of the party;

5 - the request must be made no later than 6 months from the discovery of the new fact and within 10 years from the delivery of the judgment.

Once all the conditions have been fulfilled, the Court will declare the admissible application and according to Article 99 of the Rules of Procedure, it sets, after consulting the parties, the time-limits for any subsequent proceedings which it considers necessary to hear the merits of the action. In this respect, the review also includes two phases, one in which it is decided whether or not to accept the petition for revision in principle, and the second, similar to the review procedure under the common law.

The Court, however, does not welcome such requests positively and is demanding for the qualification as a ,new fact" of the circumstances presented to it. Thus, in its judgment on the Revision of the Judgment of 11 July 1996 on the Application of the Convention on the Prevention and Punishment of the Crime of Genocide (Bosnia and Herzegovina v. Yugoslavia) [1], the Court held 
that, according to Article 61 par 1 of the Statute, a request for revision of the judgment may be submitted in case of „discovery" of facts which ,were not known to the Court at the time of the judgment". These aspects are the characteristics of a ,new' fact in the terms of article 61 par 2 [1:28-29]. Both paragraphs therefore refer to the existence of a fact at the time of the judgment and are subsequently discovered. Thus, a fact that occurs a few years after the pronouncement of the judgment will not be a „new” fact in the terms of article 61 of the Statute.

In addition to the above-mentioned characters, the Court ruled in its judgment on the Request for revision and interpretation of the judgment of 24 February 1982 in the Continental Plain (Tunisia v. Libya) [2] that, to the extent that knowledge of the new facts invoked taken from the pleadings in the substantive examination of the case or from the materials submitted to the Court and thus, become known to the Court, it is also presumed that the party requesting the review of the judgment is also known. Therefore, the Court must be aware of any fact on which the materials presented by the parties are based in order to determine whether or not it refers to it in its final judgment. Similarly, neither the parties may plead ignorance of the fact as long as it has been mentioned in the pleadings of the opposing party or in the documents annexed to the pleadings, or in any other way submitted to the Court [2: 15].

At the same time, if, in examining the request for review, the Court establishes that a condition out of those stipulated in Article 61 par 1 of the Statute is not met, it will not examine the other conditions. Thus, in its judgment on the Request for revision and interpretation of the judgment of 24 February 1982 in the Continental Plain (Tunisia v. Libya), the Court found that Tunisia's negligence in obtaining the compulsory data on the concession failed to satisfy one of the conditions of the admissibility of the petition for review and the Court considers it inappropriate to determine whether the review request was made within 6 months of the discovery of the facts on these data [2: 34].

This appeal is also provided by the ECHR Regulation, at article 80 . If a finding of a fact which by its very nature could have exerted a decisive influence on the outcome of a case already examined and which, at the time of the judgment, was unknown to the Court and could not reasonably be known on the one hand, the latter may refer the ECHR to a request for review of the judgment in question.

The appeal period is of 6 months and runs from the date when the party was aware of the fact discovery. The request for review must state the decision whose revision is required, contain the necessary indications to determine whether the conditions laid down in the Regulation have been 
met and be accompanied by a copy of any evidence on which it is based. In McGinley and Egan v. The United Kingdom [3], the Court pointed out that since Article 44 of the ECHR enshrines the principle of the definitive nature of its judgments, since a request for review calls into question that nature, it will be taken into account only exceptionally [3, paragraph 30]. Such a request requires a rigorous examination of the situation presented by the party requesting the review of the judgment.

As a rule, a petition for review is examined by the contentious party that issued the judgment under review, as we pointed out in paragraph 2.2 of this study. The settlement of the request in the review is done in two stages. In the first stage, the Chamber or the Grand Chamber may decide to reject the request, on the ground that nothing justifies its examination. If it is not possible to bring together the jurisdictional formation in the original composition, the ECHR president shall constitute or complete it by drawing lots.

In the second stage, if the application has not been rejected, the Registrar shall communicate it to all other interested parties, inviting them to submit any written observations within the time limit set by the President. It also sets the date of the hearing, if the judicial body decides to hold one. We recall that the petition for review is solved by a judgment [4:228].

Arbitral trials may also be subject to the review procedure under the conditions laid down in The Hague Convention of 1907. Accordingly, article 83 of the Convention, in order to be able to use the review of the arbitral award, the parties are obliged to reserve this right in the arbitration agreement, in which it also sets the deadline for the submission of a request for review of the sentence. at the same time, the Convention establishes that the petition for review may only be referred to the court which delivered the sentence and, as in the cases of the permanent courts, is only made when a new fact is discovered.

As for TIM, it is curious that the Statute of the Tribunal does not devote the review or the appeal procedure to the decision taken by the forum. However, the internal Regulation of TIM establishes in Article 127 that the request for review may be submitted only if a finding of decisive nature, unknown at the time of the examination of the substance of the case unknown to the General Court and undue to the negligence of the applicant party, is found. The review request is to be submitted within six months of the discovery of the matter and before the expiration of ten years from the date of the judgment. The decision on the review request takes the form of a judgment of the General Court [5, art. 129]. 
The CIP Statute also provides for the possibility of reviewing convictions and sentences handed down by the jurisdiction of universal repression. Thus, in accordance with article 84 par 1, the convicted person, the spouse or children, the prosecutor in the interest of the convict, as well as the third person expressly authorized by the deceased in trial for filing the application, may request the Board of Appeal to review the conviction or sentence issued. The Statute establishes an exhaustive list of alternative reasons which may be invoked to justify the request for revision as follows:

- the discovery of new unknown material during the examination of the case (if ignorance is not imputable to the requesting party of the review) and sufficiently meaningful (knowledge of it could reasonably lead to the adoption of another verdict in the primary process);

- establishing that the basic evidence of the decisive role that led to the decision was false or distorted;

- one or more magistrates participating in the trial have committed serious wrongful acts of violation of their professional duties that justify their recusal.

The Board of Appeal shall decide on the application, if it considers it unfounded, it shall reject it. If the Board of Appeal concludes the admissibility of the application, it has three options: reinstates the original chamber that has delivered the judgment, constitutes a new contentious party or retains its jurisdiction over the petition for review.

\section{Conclusions}

We emphasize that, based on the specificity of international criminal jurisdiction, the procedure for reviewing CIP decisions is more similar to domestic criminal procedures than international ones.

The Statute of the International Criminal Tribunal for the former Yugoslavia [6] provides in Article 26 revision of procedures. Thus, if a new fact is discovered in the proceedings before the court of first instance or the Appeals Chamber, of decisive nature for the adopted court act, the sentenced person or the prosecutor is entitled to file a request for revision of the issued decision.

The system of legal means against the opposability of the international jurisdiction is incomplete in the area of international law. Even if they were inspired by the domestic law of the States of Appeal, they differ from those currently provided by national law by the way and limits of exercise, and the competent jurisdictions to examine them. Recourse to 
them is always, with the exception of the scorn of universal, rare repression, and the withdrawal of the international exceptional jurisdiction.

\section{References}

[1]. Revision of the Judgment of 11 July 1996 on the Application of the Convention on the Prevention and Punishment of the Crime of Genocide (Bosnia and Herzegovina v. Yugoslavia) IJC Judgment of 3 February 2003. Available from: https://www.icj-cij.org/docket/files/122/8247.pdf (accessed at 27. 05.2015).

[2]. Request for revision and interpretation of the judgment of 24 February 1982 in the Continental Plain (Tunisia v. Libya), IJC judgment of 10 December 1985. Available from: https://www.icj-cij.org/docket/files/71/6526.pdf (accessed at 27. 05.2015).

[3]. ECHR, McGinley and Egan v. The United Kingdom, review decision of 28 January 2000.

[4]. Popescu C-L. Protectia international a drepturilor omului-surse, institutii, procedure. Bucharest: All Beck; 2000.

[5]. Regulation of the International Tribunal for the Law of the Sea (ITLOS / 8), amended on 17 March 2009. Available from: http://www.itlos.org/start2 fr.html, accessed at 23.04.2017.

[6]. Statute of the International Criminal Tribunal for the former Yugoslavia 